\title{
PSYCHO-EDUCATIONAL CONTEXT OF SUPPORTING SENIORS IN POLAND, USING TOOLS FROM THE EDUSENIOR PROJECT
}

Agnieszka Kozerska

Elżbieta Napora

Malgorzata Piasecka

Alina Gil

Joanna Górna

Urszula Nowacka

Luis S. Ochoa

Jan Długosz University in Częstochowa

\begin{abstract}
The purpose of the article was to capture the psycho-educational context of support for Polish seniors by institutions that have used the methods developed in the Edusenior project. The areas requiring seniors' education and the scope of work carried out by the developing institutions, government, and NGOs initiatives to raise the quality of life for seniors have been elucidated in the following article. The products obtained from the international Edusenior project, in which the preliminary results were evaluated by experienced Polish reviewers, comply with the above requirements.
\end{abstract}

Key words: seniors, educational needs, quality of life

\section{Introduction}

The strategy of psycho-educational support for older people is one of the priorities of social policies around the world, and also in Poland. It is a result of demographic changes caused by the aging population at the macro level. That is why in gerontology, the social issue of optimistic, happy, vital and active aging is being raised more and more often (Zych, 1999). The change is also observed in the form of care and support for older people, with the consistent application of the principle that seniors remain in their place of residence as long as possible, supporting their independence, self-reliance and activity. Forms of support no longer include only the material and financial dimension, but also involve the mental and emotional dimension (Zych, 2003). In addition to those legitimized by the government, such as social senior homes, day care centres, social assistance centres, institutions supporting seniors also include those run by so-called third sector institutions, which are types of non-governmental organizations, societies, associations, and cultural institutions not funded by the state. This article aims to capture the psycho-educational context of support for the institutions mentioned earlier, regarding Polish seniors. The educational needs of seniors will be mentioned and the forms of psycho-educational support. Next, the fragment of work concerning the Edusenior research project will be presented. 
Edusenior is a multilateral project of the Grundtvig sub-program implemented under the European Union Programme "Learning for Life". The project is implemented by the seven partner institutions from 7 European countries: Spain, Finland, Italy, Latvia, Poland, Hungary and Bulgaria. Duration of the project: 01.11.2011 - 01.30.2014. The aim of the project is to improve the quality of work of institutions dealing with seniors' education and to improve the quality of life of seniors who participate in the educational offer targeted to their needs. In order to achieve these objectives, the research team has developed two publications: a guide to the basics of senior education and a set of assessment tools for senior education. They were evaluated by reviewers from several European countries. The article presents the results of reviews written by 10 Polish reviewers.

\section{The educational needs of seniors}

Educational needs are a stimulator of cognitive activity for an individual. They are met by the educational actions taken by an individual, understood here as "actions that create the possibility for learning, gathering experience, understanding the surrounding reality, provoking and reinterpretation of reality" (Małecka, 2000:134). The educational needs of seniors depend on the circumstances and conditions in which these people live in; they largely derive from the culture. The educational activities undertaken by seniors do not only serve in acquiring knowledge and skills, but also in building their own identity, creating themselves, making sense of their own lives. Taking on educational activities for an elderly person requires prior execution of his/her right to design his/her personal development and to be in charge of it. It also requires a trust in his/her own ability to manage this development.

By analyzing statements of women aged 65 and over on the educational activities undertaken by them, Sulik (2009) has distinguished activities taken in familiar and unfamiliar areas. Educational activities in the unfamiliar areas are related to the implementation of educational needs coerced by the rapidly changing reality, breaking the limitations associated with age and health deterioration, the undertaking of new social roles. Educational activities in these areas also arise from the educational needs resulting from the previously unrealized desires, plans and dreams for which there was not enough time earlier in life. On the other hand, familiar areas include areas of activity and social roles in which seniors have been realizing their potential for a longer time (Sulik, 2009:145).

They involve previously performed work or social roles that even before retirement were practiced to perfection and with passion. The perception of which area a person sees as familiar is an individual matter. However, based on statistical studies and research reports, several basic unfamiliar areas can be distinguished for today's elders. 
Educational needs of the unfamiliar areas may be related to social exclusion prevention, may motivate one to take on actions that increase the chances of ensuring a full participation in society. They are also associated with the human desire for independence, the release of various forms of bondage from the stereotypical thinking about old age being associated, therefore, with the emancipatory function of education. In addition, they are associated with the search for remedies in difficult and problematic situations-being associated with the instrumental function of education in this case (Dubas, 2008:60).

One of the unfamiliar areas for the majority of seniors in Poland is the area of technology the use of information technology. The lack of ability to use modern technology may be the cause of marginalization of older people. Research conducted within the Social Diagnosis 2013 project (Batorski, 2013) show that the factors most related to Internet use in Poland are age and education. The Internet is used by $14 \%$ of people aged 65 and over (Batorski, 2013:14). Intergenerational differences in this respect may be the source of many negative social phenomena. People who do not use the Internet do not have access to information, and this is related to difficulties in functioning in various areas of life (e.g., participation in culture, performing administrative tasks, participation in institutions related to health care, etc.). The ability to use information and communication technologies is increasingly becoming a prerequisite for participation in various areas of life, and those who do not have the necessary skills are excluded from social and economic life. The authors of the Diagnosis 2013 report note that older people who do not use modern technology function differently in the world; they deal with everyday life problems in a different way compared to younger individuals (97\% of people aged 25-36 years in Poland use the Internet). These differences can be a reason for communication difficulties between young people and seniors (Batorski, 2013).

Another unfamiliar area for many Polish seniors is the different aspects of physical aging. Educational needs of seniors in this area are related to the maintenance of good physical health as long as possible, or learning to live with some kind of health problem or disability. Physical or mental incapacity can also be a reason for social exclusion. Therefore, the cognitive activity associated with caring for physical and mental health, as well as being physically active in general, is important. Research conducted in Poland by the Central Statistical Office shows that $85 \%$ of people above 70 years of age rate their health condition lower than "good"; in the 60-69 age group, the percentage of seniors that evaluate their health at the same level was equal to $72 \%$. Documentation by the World Health Organization (WHO, 2002) emphasizes that the term health is now widely understood not only as the absence of disease, but refers to physical, mental and social welfare. Thus, a person who takes care of their health does not limit himself/herself only to activities related to the strengthening of physical health, prevention of disease or disability, but also takes part in social life, is involved in social issues, is able to apply effective strategies for coping with 
difficult situations, establishes close relationships with other people (Kościńska, 2008). Social exclusion is related with the experience of loneliness. Educational activities undertaken within the framework of social activities, such as volunteering, working for the local community, or establishing new social relations, may serve in satisfying the needs of usefulness, acceptance and emotional bonding. According to Wnuk (2013), meeting these needs is identified with a sense of meaning in life by older people.

An unfamiliar area of educational activities is situations in the biography seen as a crisis or a breakthrough. Such a breakthrough situation may be the birth of a first grandchild, death of a spouse, marriage crisis, etc. Such situations may become milestones that stimulate educational activities. If grandparents want to help in their grandchildren upbringing, the birth of their first grandchild requires them to undertake intensive educational activities (Kargul, 2005). The world in which they brought up their children is different from the world in which their grandchildren live. Therefore, they need to make restoration, reorganization of their knowledge not only in the small area of child care, but also in other areas of daily life. Difficult situations, breakthroughs are educational in the sense that they force reflection on their current way of interpreting the world, the perception of one's own place in this world. They cause the individual to begin to realize the assumptions that have been thoughtlessly taken in interpreting life events. The realization of these assumptions often urges to make the effort, involving the search for new ways of interpreting, with the consequence of developmental change in the cognitive subject (Mezirow, 1996; Kozerska, 2010).

\section{Forms of psycho-educational support for seniors in Poland}

The starting point for consideration of psycho-educational support for seniors can be made in thesis that individual health is the biological embodiment of psychological well-being (Czapiński, 2004:157). The dimensions of this welfare are self-acceptance, control over the environment, autonomy, positive relations with others, personal growth, purpose in life (Czapiński, 2004:153). Selfacceptance is the key aspect of well-being that reflects the positive self-attitude and awareness of personal strengths and limitations. Control over the environment means the ability to create and to nurture the environment that suits individual needs. Autonomy, in turn, is the ability to follow one's own convictions, and the positive relationships with others include the power, pleasure and joy which a close, authentic contact with another human being gives. Personal development, another element of well-being, is the ability to continuously use the talents and potential that serves the realization of life's purpose, meaning the searching and finding of the sense of life in constant confrontation with life's adversities (Czapiński, 2004:53-156). Such an integrated approach to health implies that an activity's proposal supporting 
health first requires the reformulating of the medical concept of "quality life" for seniors and the transferring of emphasis on the broadly understood human wellbeing physical, mental and social.

Meanwhile, the conventional understanding of health among older people in Poland organizes their lives primarily around the so-called health services: i.e., medical services $(98 \%)$, various types of diagnostic tests $(95 \%)$, immunization $(35 \%)$ and rehabilitation (45\%). Many seniors know and understand the need for a holistic approach to health (up to $60 \%$ ), but few of them even make use of the disease prevention offer. Physical activities, such as swimming (10\%), gymnastics (11\%), and dancing (3\%) are marginalized as well as meetings with a nutritionist (7\%), trainings (4\%) and workshops related to a healthy lifestyle (2\%); a small number of elderly people participate in them (Diagnosis, 2012, p. 14).

An important element of good aging is physical activity. This is an irrefutable fact. Unfortunately, in the majority of elderly people, a clear decrease in activity, being limited to daily activities, is observed. Meanwhile, the maintenance of a high physical activity in seniors is one of the factors predicting longer life expectancy. It enables older people to maintain their autonomy and independence, and thus contributes to the improvement of their quality of life (Kaczmarczyk \& Trafiałek, 2007). The following are among the forms of support in this area: 1) competitive sport targeted to seniors, 2) recreational and sporting facilities available for the elderly on preferential terms, 3) truism offers and recreational activities for older people, such as guided tours; 4) handicraft activities such as knitting, tapestry, embroidery, sculpture; 5) physical activities such as dance, relaxation gymnastics, nordic walking (Report IRSS, 2010:105). Research shows that the most common form of physical activity supports among seniors are trips and that the non-governmental sector takes a significant part in the implementation of this most desired service. It comprises more than $60 \%$ of all entities undertaking this service (Report IRSS, p. 113). However, in this area, a matter of great importance is to change the mindset of senior citizens through systematic educational interactions.

Seniors encountering various emergencies such as illness, physical disability, and many others, are faced with the necessity of psychological support. Many forms can be pointed out in this area of support, including the following: 1) class therapies for the elderly, 2) psychological support through home visits, the designation of the place and time of meetings with a psychologist; 3) coaching to prepare seniors to live with the illness and/or disability; 4) intervention/ emergency assistance for the elderly and their families/caregivers; 5) diagnosis of the range of addiction among the elderly; 6) educational activities related to the risk of addiction among the elderly addressed to persons who care for the elderly; 7) counseling and assistance for the elderly addicted to alcohol, medical drugs, and members of their families; 8) starting off, as part of the so-called blue line (emergency line), an information centre about abuse and violence against 
seniors; 9) intervention-support programs for senior citizens - victims of crime, abuse, accidents and disasters; 10) the organization of support groups for older people experiencing abuse; 11) mediation in cases of generation conflicts in a family with an older person (Kawula, 2007:88).

The analysis of the IRSS Report (2010) shows that among the top rated services in terms of their need for implementation were those that are not often offered to seniors. It is worth mentioning the following services here: counseling in preparation for the elderly to live with the illness and/or disability and psychological help. Both of these services should be performed more frequently than it happens currently (IRSS Report, p. 94). In addition, the report notes that the above services are largely being implemented through the participation of the third sector (NGOs). In the case of the first service, nearly every third assistance in this category is implemented by the NGO. An even greater percentage of the service delivery by these organizations is for conducting active therapy for older people (IRSS Report, p. 96). A particular importance in the context of seniors is the strategy of lifelong learning. It must be understood in the terms proposed in the Resolution of the European Council of 27 June 2002 as the notion, which should involve learning to the late retirement phase, including the entire spectrum of formal learning (in schools and other institutions of education), non-formal (in institutions outside the education system) and nonformal (natural). In addition, it should apply to all lifelong learning activities aimed at developing knowledge, skills, and competences within personal, citizen, social and employment-oriented perspective. The education of seniors should also be considered in the broad context of cultural changes and civilization challenges. Not without reason, the year 2012 has been declared by the EU Council as a European Year for Active Aging and Intergenerational Solidarity. In Poland, it was also celebrated as the Year of Universities of the Third Age. Seniors, like any other social group, create a knowledge society, where knowledge becomes the greatest asset in the development of individual and social dimension. The spectrum of skills recognized as necessary in order to fully participate in the $21^{\text {st }}$ century is very broad, and their achievement prevents the processes of marginalization and exclusion of seniors. The catalog of these skills includes, among others: information literacy, creativity and innovation, critical thinking and problem solving, communication including intergenerational communication, cooperation within a group and communities, media literacy in regards to skills for the use of digital media, proficiency with the use of informationcommunication technology tools, flexibility and adaptability, initiative and selfdetermination of one's life, ability to function in a diverse and multicultural environment, productivity, leadership skills and responsibility (21st Century Skills Map, 2008).

Educational programs strictly targeting seniors can be analyzed in two contexts: first, as the strengthening of older people's capacity to facilitate their personal 
development, intellectual activity and personal fulfillment for this generation, and secondly, for the utilization of the potential and experience of older people in community life, social inclusion and intergenerational education.

If we focus our thinking on the first context, we can identify the following areas of activity: 1) gerontology education targeted to seniors, 2) educational services for the elderly, including activities offered by Universities of the Third Age, counseling for people in the preretirement age in preparation for the role of pensioner, trainings familiarizing seniors with new technologies that help in everyday life (banking, ATMs, mobiles), training on information technology, including computer and Internet use; 3 ) training to improve the maintenance of a well-groomed appearance; 4) educational activities for elderly discrimination prevention (Szukalski, 2009).

Research undertaken for the indicated areas give an interesting picture of the state of education, which is characterized by a large disproportion between the frequencies of services offered. Counseling for people of preretirement age, preparing them for the role of pensioner, is least often offered. Such a service is performed only in $3.1 \%$ of surveyed municipalities (IRSS Report, 2010:115) In comparison to the services analyzed above, far better looking is the implementation of the services in the fields of gerontological education targeted to older people, technology and information services, as well as creating Universities of the Third Age. By far, the most available service in the area under discussion is the activities offered for the elderly within the universities of the third age. The report "ZOOM na UTW" (2012), prepared by the Society for Creative Initiatives "ę" in the scientific cooperation with the Institute of Applied Social Sciences, University of Warsaw, shows that in Poland there are nearly 400 Universities of the Third Age (UTW), where most of them develop mainly in the cities (seniors have the easiest access in Warsaw and cities with residents up to 50,000). In rural areas, Universities of the Third Age comprise only 11 percent. The worst access to UTA is in the świętokrzyskie, podlaskie and podkarpackie provinces ("Zoom na UTW" Report, p. 17-18). The report also shows that the Universities of the Third Age act mostly as non-governmental organizations: independent associations (41 percent); foundations, in rare cases ( 1 percent); 12 percent of UTA are under "the umbrella" of some larger associations or foundations; 19 percent of UTA operate within a public or nonpublic higher education institution; 22 percent are subject to the local government institution, usually a community culture center, but sometimes UTA operate within the library or other entity appointed by the office of the municipality or city ("Zoom na UTW" Report, pp. 24-26).

If we look at the education of seniors in the context of utilizing their potential and experience in community life and social integration, as well as intergenerational education, the offer of services in this area is also broad. It may include the following fields: 1) the functioning of the advisory group in the structure of local government, made up of older people having an impact on 
matters concerning the community and the oldest generation; 2) self-help activities among older people such as senior nurses offering care, legal advice, time banks, etc.; 3) actions to support the family ties of the elderly; 4) actions to support neighbourhood bonds of the elderly; 5) activities incorporating seniors in the educational process in preschools; 6) activities incorporating older people in the didactic process at schools such as history and educational lessons, etc.; 7) activities integrating generations in cultural programs, such as cultural events involving people of all ages; 8) activities to promote a positive image of older people, such as regular events, conferences, competitions, presentations of works and the creativity of older people; 9) the development of volunteering among older people and the development of volunteering for the support of older people (IRSS Report, 2010).

Data analysis of this report shows that in the area under discussion there is a very large diversity of services considering the frequency of their occurrence. This spread is determined by a group of services/activities very rarely implemented, e.g., the functioning of the advisory group in the structure of local government consisting of the elderly, self-help activities among older people such as self-help banks, activities incorporating older people in the educational process in preschools, and a group of services/activities that is relatively often implemented, such as activities integrating generations in cultural programs (IRSS Report, p. 128).

Senior education in Poland has become a reality and it already has a history, especially concerning Universities of the Third Age. The first step to the success of the popularity of this educational form was and still is the awakening of universal social awareness that this is a valuable stage of life. As in any other stage, it is characterized by the desire of acquiring knowledge and learning new skills, and retirement is an excellent moment to start studying once more. Institutions encouraging the resuming of education emphasise the fact of optimal, creative use of leisure time, of meeting people who share a common interest, of initiation into new areas of knowledge often needed to continue the career as well as of active participation in culture. However, there is still much to be done in the area of psycho-educational support for older people. At the turn of the 20th and 21st centuries, Synak wrote that "never has the world been as allied against the older generation as it is now, never has the social position of the old man been so low" (2002:8). And what is the situation now, after several years? We see a continuous process of change for the better, in which the number of elderly is still growing and will be growing in our population (Worach-Kardas, 2003). This situation requires a professional, integral approach to the problem of old age and it requires the development of the most competent, supporting educational projects. 


\section{References of the project results}

Within the Edusenior ${ }^{4}$ project, the Polish research team ${ }^{5}$ has worked on the adaptation of two products: 1) a set of evaluation tools for educational institutions educating seniors to improve their quality of life (Escuder-Mollon, Cabedo, 2013), 2) a guide (Escuder-Mollon, Cabedo, 2013) addressed to teachers, trainers, educators, animators, technicians, managers and those who want to know more about the relationship between the quality of life of seniors and their education as well as about the relationships with seniors.

Using the evaluation questionnaires, the task of reviewers was to assess the Guide: Education and the quality of life of seniors and Evaluation Toolkit for Educational Institutions. Increasing the Impact of Education on the Quality of Life of Seniors. In his/her opinion, each reviewer had to comment on the usefulness of these products. The reviews were presented in the form of a quantitative assessment scale ( 1 to 5 ) and were also formulated as answers to the open questions.

Selection and the reviewers' description. Reviewers were randomly selected, ten different specialists with a higher education level, representing teachers, staff, local government policymakers. Selection of the reviewers was determined by five criteria: 1) having competence with a basic knowledge of the concepts of quality of life, the needs of seniors, methodologies and educational activities; 2) having at least 3 years of documented experience in adult education; 3) having experience in the evaluation processes, such as collecting information, conducting interviews, reporting; 4) knowledge of methodology toolkit assessment; 5) pedagogical education. The data describing the reviewers are presented in Table 1.

Table 2 below presents the general opinions of reviewers on both the Guide and the Evaluation Toolkit for Educational Institutions. Increasing the Impact of Education on the Quality of Life of Seniors.

Additionally, in the opinion of the reviewers, it is worth emphasizing the clear structure of the Guide, a way of discussing the theoretical issues, which gives the allowance for clear and logical formulation of questions in the survey. The explanatory role of the diagrams and drawings, allowing a better understanding of the information presented in the Guide, was also highlighted. The second product was similarly rated, Evaluation toolkit, increasing the importance of systematic content presentation both in the aspect of education and the quality of life.

\footnotetext{
${ }^{4}$ The project is financed by the European Commission under the Lifelong Learning Programme of the European Union, No.: 518227-LLP-1-2011-1-ES-Grundtvig-GMP. For more information on the project, please visit http://www.edusenior.eu; information about the Lifelong Learning Programme can be found at http://ec.europa.eu/education/lifelong-learning-programme.

${ }^{5}$ The Polish research team: Gil A. - coordinator, members: Nowacka U., Ochoa LS, Górna J., Kozerska A., Piasecka M., Napora E.
} 


\section{Reviewers' description}

\begin{tabular}{|c|c|c|}
\hline No. & Descriptive variables & $\begin{array}{c}\text { Descriptive statistics } \\
\text { n }(\%) / M ; S D^{*}\end{array}$ \\
\hline 1. & $\begin{array}{l}\text { Sex } \\
\text { F } \\
M \\
\end{array}$ & $\begin{array}{ll}9 & (90) \\
1(10) \\
\end{array}$ \\
\hline 2. & $\begin{array}{l}\text { Age group } \\
35-44 \\
45-54 \\
65 \text { and over }\end{array}$ & $\begin{array}{ll}4 & (40) \\
3 & (30) \\
3 & (30) \\
\end{array}$ \\
\hline 3. & $\begin{array}{l}\text { Education } \\
\text { Master's Degree } \\
\text { PhD }\end{array}$ & $\begin{array}{l}4(40) \\
6(60)\end{array}$ \\
\hline 4. & $\begin{array}{l}\text { Occupation } \\
\text { Teacher } \\
\text { Technician } \\
\text { Director }\end{array}$ & $\begin{array}{ll}8 & (80) \\
1 & (10) \\
1 & (10)\end{array}$ \\
\hline 5. & $\begin{array}{l}\text { Work Experience } \\
M \\
S D\end{array}$ & $\begin{array}{l}26,9 \\
13,52\end{array}$ \\
\hline
\end{tabular}

$M$ - means arithmetic mean; $S D$ - standard deviation

Table 2

The reviewers' evaluation of Edusenior project products

\begin{tabular}{|c|c|c|c|}
\hline Products & Language & Structure & General opinion \\
\hline Guide & Understandable & $\begin{array}{c}\text { Chapters retain the } \\
\text { proportions }\end{array}$ & Very good \\
\hline Evaluation Toolkit & Clear and logical & $\begin{array}{c}\text { Clear and } \\
\text { comprehensible }\end{array}$ & Very good \\
\hline
\end{tabular}

\section{Guide Review}

The Guide has been prepared for caregivers, entertainers, teachers, staff, technical staff, supervisors and managers (Escuder-Mollon, Cabedo, 2013) who wish to obtain knowledge about the possibilities of influencing the quality of life of seniors through education. The Guide recognizes different aspects concerning the education of seniors, ranging from basic theoretical concepts to practical issues supported by examples and good practice. The first three chapters concern the validity of the issues discussed: 1 . quality of life, 2. aging, 3. social functioning of seniors. The next four chapters relate to education and include: 4. form of educational classes, 5. pedagogy, 6. program content, 7. knowledge and competence of the staff and trainers working with seniors. In the opinions on the Guide, each of the reviewers had to assess the suitability of the individual sections of the Guide, its failures, and expectations. The information collected 
from reviewers was supposed to further improve the quality of the results of this project. Results of the reviews are shown in Table 3.

Table 3

Reviewers' evaluation of the chapters of the Edusenior project guide

\begin{tabular}{|c|c|c|}
\hline \multirow{2}{*}{$\begin{array}{l}\text { Titles } \\
\text { and the } \\
\text { order of } \\
\text { chapters }\end{array}$} & \multicolumn{2}{|c|}{ Adequacy of the presented content } \\
\hline & The most useful content & Deficiency and shortcomings \\
\hline $\begin{array}{l}\text { Introducti } \\
\text { on }\end{array}$ & $\begin{array}{l}\text { definitions of the quality of life, } \\
\text { justification of the importance of educational } \\
\text { institutions to improve the quality of life, } \\
\text { preview of the Guide content }\end{array}$ & health of seniors \\
\hline $\begin{array}{l}\text { The } \\
\text { quality of } \\
\text { life (1) }\end{array}$ & $\begin{array}{l}\text { multifaceted and the clear approach to the } \\
\text { quality of life concept }\end{array}$ & $\begin{array}{l}\text { list of Polish literature, } \\
\text { taking into account the } \\
\text { relationship of the quality of } \\
\text { life with the economic and } \\
\text { political situation of the } \\
\text { seniors' country }\end{array}$ \\
\hline Aging (2) & $\begin{array}{l}\text { the justification of the educational needs of } \\
\text { seniors, providing professional knowledge } \\
\text { necessary to work with the elderly }\end{array}$ & $\begin{array}{l}\text { current Polish literature, } \\
\text { physical effects of aging in } \\
\text { seniors, } \\
\text { reference to the toolkit }\end{array}$ \\
\hline $\begin{array}{l}\text { Social } \\
\text { dimension } \\
\quad(3)\end{array}$ & $\begin{array}{l}\text { description of the changing social roles taken } \\
\text { up by seniors, } \\
\text { overview of data presenting population aging, } \\
\text { current data regarding seniors }\end{array}$ & $\begin{array}{l}\text { the procreative role of a } \\
\text { family in the process of } \\
\text { aging, } \\
\text { implementation of a social } \\
\text { policy improving the quality } \\
\text { of life of a senior }\end{array}$ \\
\hline Models (4) & $\begin{array}{l}\text { Models of education in different countries in } \\
\text { terms of non-formal education, } \\
\text { intergenerational learning outcomes }\end{array}$ & Formal senior education \\
\hline $\begin{array}{l}\text { Pedagogy } \\
\quad(5)\end{array}$ & $\begin{array}{l}\text { active ways of learning: reflective, self- } \\
\text { directed learning, intergenerational, } \\
\text { possibilities and limitations of cognitive, } \\
\text { physical, social, and emotional capability in } \\
\text { seniors' learning }\end{array}$ & Current Polish literature \\
\hline $\begin{array}{l}\text { Program } \\
\text { content (6) }\end{array}$ & $\begin{array}{l}\text { presentation of the European educational } \\
\text { programs for seniors, } \\
\text { good practice in the preparation of trainers, } \\
\text { list of key competencies of trainers }\end{array}$ & $\begin{array}{l}\text { reference to the curren } \\
\text { projects implementation on } \\
\text { the subject matters }\end{array}$ \\
\hline $\begin{array}{l}\text { Staff, } \\
\text { trainers (7) }\end{array}$ & $\begin{array}{l}\text { description of the role of a modern and } \\
\text { innovative teacher/trainer in the education of } \\
\text { seniors, } \\
\text { describing modern trends in the education of } \\
\text { seniors }\end{array}$ & $\begin{array}{l}\text { depicting personality } \\
\text { predisposition of } \\
\text { trainers/teachers intending to } \\
\text { work with seniors, } \\
\text { presenting bibliographic } \\
\text { sources }\end{array}$ \\
\hline
\end{tabular}


Chapters 3, 4, 5 and 6 of the Guide were rated as satisfactory and with no major objections, including the statements and their related explanations of "multidimensionality of the approach of the quality of life concept and senior education", "new social roles undertaken by seniors that serve their quality of life." The authors of the Guide approach on "new educational needs of seniors", "the importance of non-formal learning and the benefits of intergenerational transmission" was accentuated. In addition, the chapter was complemented with examples of good practices aimed at preparing trainers to work, and the precise identification of key competencies needed in educating seniors was emphasised. However, from the point of reviewers' obligation, several weaknesses of the product were noted in reference to Chapter 1 in which "it refers to the definition of the English, American authors, in which the recognition of the quality of life is marked by the culture and mentality of society (F, 25 years of professional experience). And "the quality of life was treated intuitively and too broad" (F, 46 years of professional experience). These elements, in the opinion of the reviewers, need improvement and enhancements.

\section{Reviews of the toolkit evaluation}

The evaluation toolkit (Escuder-Mollon, Cabedo, 2013) contains a methodological description, a list of indicators, and institution evaluation procedures that help interested persons to check the quality of educational activities undertaken by the institution, identify the weak points and correct them according to the recommendations. The tools are an integral part of the package, along with the Guide. The developed tools include two dimensions: educational and psychological well-being. Each of the dimensions are described using the seven indicators, the first takes into account the following parameters: 1. institutions, understood as a place and a form of services organized and provided; 2. management and organization; 3. educational models: formal, informal, non-formal; 4. methods of education; 5. implemented courses for seniors; 6. forms of activity; and 7. staff and trainers. On the other hand, the second dimension refers to the quality of life and is expressed by the following indicators: 1. physical health, 2. mental health, 3. integration through the improvement of communication skills, 4. involvement in educational institutions, 5. improvement of the ability to analyze, 6 . increase of self-esteem, and 7. self-fulfillment and peace of mind. The assessment of the evaluation tools is presented in Table 4.

In general, the evaluated product according to reviewers is cognitively interesting and valuable from the point of view of the subjects dealing with seniors, thus useful to the teaching practice and to develop programs working with seniors. 
Proceeding of the International Scientifical Conference May $23^{\text {th }}-24^{\text {th }}, 2014$

Table 4

\section{Reviewers' evaluation of the Edusenior project evaluation toolkit}

\begin{tabular}{|c|l|c|}
\hline $\begin{array}{c}\text { General } \\
\text { indicator }\end{array}$ & \multicolumn{1}{|c|}{ Adequacy of the presented content } \\
\cline { 2 - 4 } educational & $\begin{array}{l}|c| \\
\text { Thest useful content } \\
\text { Shortcomings }\end{array}$ \\
\hline $\begin{array}{c}\text { close connection between education dimension and } \\
\text { the quality of life, } \\
\text { practical guidance on the requirements and } \\
\text { life }\end{array}$ & $\begin{array}{l}\text { precise definition of the objectives and elements to } \\
\text { be evaluated, } \\
\text { specific description of the information gathering } \\
\text { and reporting procedures } \\
\text { clarification of the competence of the evaluator }\end{array}$ & no objections \\
\hline
\end{tabular}

\section{Recommendation of the project results}

The influence of education on the quality of life of seniors is an important social issue, though still poorly understood in Poland. Edusenior project results, as innovative aids, represent a first step to help the employees of the institutions dealing with seniors to make them more skilled, which will increase the activity of seniors, their participation in social life, integration, and self-realization. At the same time, the society will benefit from more motivated and active seniors. In addition, the products pay particular attention to the academic environment and other researchers on the subject in order to innovate the field of adult education (Gil, 2013). The education will strengthen measures to prevent social exclusion of seniors and will give the allowance for the identification of the best practice of senior activation in the Polish context (Napora, Kozerska, Schneider, 2012).

\section{References}

1. Batorski, D. (2013). Polacy wobec technologii cyfrowych-uwarunkowania dostepności i sposobów korzystania. Diagnoza Społeczna 2013 Warunki i Jakość Życia Polaków Raport. [Special issue]. Contemporary Economics, 7, (pp.317-341). Accessed from http://ce.vizja.pl/en/issues/volume/7/issue/4\#art316 (access 7.12.2013).

2. Czapiński, J. (2005). (ed.), Psychologia pozytywna. Nauka o szczęściu, zdrowiu, sile $i$ cnotach człowieka. Warszawa: PWN.

3. Zajdel-Ostrowska, M. (2012). (ed.), Diagnoza systemu pomocy $i$ wsparcia osób starszych a potrzeby seniorów $w$ województwie podkarpackim., , Regionalny Ośrodek Polityki Społecznej w Rzeszowie. Accessed from http://www.ois.rops. rzeszow.pl/dokumenty/ badaniaanalizy/diag_syst_wsparcia_osob_starszych.pdf (access 11.12. 2013).

4. Dubas, E. (2008). Edukacyjny paradygmat badawczy w geragogice. W: M. Kuchcińska (ed.), Edukacja do i w starości (pp. 43-65). Bydgoszcz: Wyd. Kujawsko-Pomorskiej Szkoły Wyższej. 
5. Escuder-Mollon, P., \& Cabedo, S. (2013). Education and quality of life of senior citizen. Uniwersytet Jaume I Castellon. Accessed from: http://edusenior.uji.es/ products.php (access 13.11.2013).

6. Escuder-Mollon, P., \& Cabedo, S. (2013). (ed.), Evaluation toolkit for educational institutions: Increasing impact on Senior learners' Quality of Life, Universitat Jaume I Castellon. Accessed from: http://edusenior.uji.es/products.php (access: 14.11.2013).

7. Gil, A. (2013). Project Evaluation toolkit on senior education to improve their quality of life. Presentation during the Interdisciplinary Seminar Activation of seniors through education, Częstochowa. Accessed from: http://www.iet.ajd.czest.pl/viewpage.php? page id=105 (access: 21.11.2013).

8. Kaczmarczyk, M., Trafiałek, E. (2007). Aktywizacja osób w starszym wieku jako szansa na pomyślne starzenie. Gerontologia Polska, tom 15, 4.

9. Kargul, J. (2005). Obszary pozaformalnej i nieformalnej edukacji dorostych. Wrocław.

10. Kościńska, E. (2008). Edukacja zdrowotna seniorów. W: M. Kuchcińska (ed.), Edukacja do i w starości (pp.193-208). Bydgoszcz: Wyd. Kujawsko-Pomorskiej Szkoły Wyższej.

11. Kawula, S. (2007). Pedagogika społeczna wobec problemów człowieka starego. W: S. Kawula (ed.), Pedagogika społeczna, dokonania - aktualność - perspektywy. Toruń: Wyd. Adam Marszałek.

12. Kozerska, A. (2010). Uczenie się człowieka dorosłego w kontekście doświadczenia krytycznego wydarzenia życiowego jako przedmiot badań. W: A. Gofron B., Lukasik B. (ed.), Podstawy edukacji. Podmiot $w$ dyskursie pedagogicznym (pp.235-264). Kraków: Impuls.

13. Małecka, B. (2000). Przestrzeń edukacyjna w życiu ludzi starszych (refleksje teoretyczne i doświadczenia empiryczne). W: M. Dzięgielewska (ed.), Przestrzeń życiowa i społeczna ludzi starszych. Łódź.

14. Mapa społecznych umiejętności XXI wieku. Fundacja „Teraz Edukacja”, Edunews.pl, Warszawa 2008. Accessed from http://www.edunews.pl/images/pdf/umiejet noscixxipl.pdf (access: 15.12 2013).

15. Mezirow, J. (1996). Contemporary Paradigms of Learning. Adult Education Quarterly, 46(3).

16. Napora, E., \& Kozerska, A., \& Schneider, A. (2012). Parentyfikacja dziadków jako czynnik resilience rodziny samotnej matki w prowincjonalnej Polsce. W: M. Komorska (ed.), Seniorzy dla młodości - młodość dla seniorów (pp. 84-95). Lublin: UMCS.

17. Raport „Instytucje wobec potrzeb osób starszych”, (2010). (eds.) Zespół Instytutu Rozwoju Służb Społecznych, Warszawa. Accessed from: http://irss.pl/wpcontent/uploads/2011/07/ Instytucje-wobec-potrzeb-osob-starszych-raport-IRSS.pdf (access: 11.12. 2013).

18. Report "ZOOM na UTW". A. Gołdys, Ł. Krzyżanowska, M. Stec, Ł. Ostrowski, (eds.), (2012). Towarzystwo Inicjatyw Twórczych "ę", Warszawa. Accessed from: http://zoomnautw.pl/wpcontent/uploads/2012/05/Zoom_na_UTW_RAPORT_calosciow y_www.pdf (access: 15.12. 2013).

19. Sulik, M. (2009). Jesień życia kobiety - aspekty edukacyjne. Chowanna 2(33), 143-154.

20. WHO (2002). Active Ageing: A Policy Framework World Health Organization, Geneva. Accessed from: http://whqlibdoc.who.int/hq/2002/who_nmh_nph_02.8.pdf (access: 1.08.2013).

21. Synak, B. (2002). Polska starość - trzydzieści lat później. W: L. Frąckiewicz (ed.), Polska a Europa. Procesy demograficzne u progu XXI. Proces starzenia się ludności Polski i jego społeczne konsekwencje (pp. 132-133). Katowice. 
22. Szukalski, P. (2009). (ed.), Przygotowanie do starości. Polacy wobec starzenia się. Warszawa.

23. Wnuk, W. (2013). Potrzeby i oczekiwania ludzi starszych. Accessed from: http://kutw. kpswjg.pl/witrynal/wnuk.htm (access: 10.12.2013).

24. Worach-Kardas, H. (2003). Starość jako wyzwanie i kwestia społeczna - nowy wymiar na progu XXI wieku. W: E. Kantowicz, \& A. Olubiński (eds.), Działanie społeczne w pracy socjalnej na progu XXI wieku. Toruń.

25. Zych, A. A. (1999). Człowiek wobec starości. Szkice z gerontologii społecznej. Katowice: Wydawnictwo Śląsk.

26. Zych, A. A. (2003). Formy opieki i pomocy dla ludzi starszych w Polsce i w innych krajach. W: Starzenie się populacji wyzwaniem dla polityki społecznej. Materiały konferencyjne ROPS, Kraków.

\section{Agnieszka Kozerska \\ Malgorzata Piasecka Joanna Górna}

Elżbieta Napora
Institute of Pedagogy, Jan Długosz University in Częstochowa, Waszyngtona 4/8, 42-200 Częstochowa, Poland

Institute of Philosophy, Sociology and Psychology, Jan Długosz University in Częstochowa, Zbierskiego 2/4, 42200 Częstochowa, Poland

Institute of Technical Education and Safety, Jan Długosz University in Częstochowa, Armii Krajowej 13/15, 42-200 Częstochowa, Poland e-mail: a.gil@ajd.czest.pl 